\title{
Application Chang's Extent Analysis Method for Ranking Barriers in the E-Learning Model Based on Multi-Stakeholder Decision Making
}

\author{
Quyen Le Hoang Thuy To Nguyen ${ }^{1}$, Phong Thanh Nguyen ${ }^{2, *}$, Vy Dang Bich Huynh ${ }^{3}$, \\ Luong Tan Nguyen ${ }^{4}$ \\ ${ }^{1}$ Office of Cooperation and Research Management, Ho Chi Minh City Open University, Vietnam \\ ${ }^{2}$ Department of Project Management, Ho Chi Minh City Open University, Vietnam \\ ${ }^{3}$ Department of Learning Material, Ho Chi Minh City Open University, Vietnam \\ ${ }^{4}$ Office of Finance and Accounting, Ho Chi Minh City Open University, Vietnam
}

Received January 19, 2020; Revised March 24, 2020; Accepted March 28, 2020

Copyright $\mathrm{C} 2020$ by authors, all rights reserved. Authors agree that this article remains permanently open access under the terms of the Creative Commons Attribution License 4.0 International License

\begin{abstract}
E-learning success model is a crucial topic, especially in the context of the Fourth Industry with artificial intelligence and virtual reality in developing countries. In practice, it is a combination of technology and education; human and system form an integrated digital learning world. E-learning has many outstanding advantages in providing flexible training and equal education to everyone, which has dramatically changed the self-study process due to the ability to customize and effectively meet the learners' demands. However, e-learning is still inferior to traditional learning and teaching in recent years. This paper explores the key barriers to e-learning success based on multi-stakeholder perspectives. The Chang's Extent Analysis Method under fuzzy logic was applied to rank the components of e-learning success model in Vietnam by defining the key barriers to its development. The incorporation of fuzzy set theory in the Analytical Hierarchical Process is superior in representing human judgments. Seven criteria were selected after justifying the experts' opinions in the in-depth interviews. The findings revealed the important order of infrastructure and technology, human resources, setting, evaluation, management and execution, support and pedagogical aspect. The results are significant for the proper action plan to promote e-learning development under the resource constraint.
\end{abstract}

Keywords Decision Science, Education Science, E-Learning, Chang's Extent Analysis Method, Success Model

\section{Introduction}

E-learning is an abbreviation of electronic learning [1]. It includes at least four approaches. It is i) technology-driven, ii) delivery-system-oriented, iii) communication-driven and, iv) an educational paradigm. Research into these approaches have resulted in various findings and have biased implication for policy. In practice, however, it is a combination of technology and education, human and system to form an integrated digital learning world. [2]. E-learning has grown drastically in the previous four decades with so much change in world education. It is forecasted that the increased trend of e-learning market size, exceed the amount of USD 240 billion by 2023 . This is justified by the cost-effectiveness, flexibility, possibilities for customization, and the use of updated learning materials in knowledge delivery. The greatest strength of e-learning is for lifelong learning and the promotion of equal educational opportunities regardless of age, gender, race, and geographical location in a knowledge-based society [3, 4]. E-learning can be the key to reaching the United Nations' sustainable development goal on education.

E-learning in Vietnam was introduced by the government resolution No. 49/CP and Directive No. 9772/BGDĐT-CNTT planning the information and communication technology (ICT) development strategy as well the prioritization of ICT in educational reform $[5,6]$. Moodle Vietnam was introduced in 2005 following the launch of the e-learning portal the year before the Ministry of Education and Training (MOET) marked a milestone in the growth path of e-learning. However, e-learning still has 
been inferior to traditional learning and teaching and, thus, e-learning success has been challenged. This paper presents the key barriers to its success using the approach of fuzzy Chang's Extent Analysis Method.

\section{Literature Review}

The literature review addresses three issues: i) the definition of success, ii) the identification of e-learning stakeholders, and iii) the key barriers to e-learning success. Based on the rich literature on barriers to e-learning development, a model of the key factors for e-learning success has been constructed with the criteria weighted so that proper action plans can be taken for the successful mission of e-learning.

\subsection{The Definition of Success and Stakeholders}

Success means positively achieving set goals [7-11]. Davis [12] further confirmed this idea, adding that the goals must be reached under the resource constraints. This definition of success suggests that each individual has a different view based on the setting. E-learning success in this study has been defined by using a multi-stakeholder perspective. At the university level, three major actors have been defined--students, instructors, and e-learning administrators $[13,14]$. However, it seems that only a one-sided view on e-learning success is reflected by this group of stakeholders. Thaufeega [15] noted that teachers and educational institutions form one of the perspectives of the digital learning world. Aparicio, et al. [16] approached the stakeholders adopted a demand and supply view, defining five major groups including i) customers (students, employers), ii) suppliers (educational institutions, accreditation bodies, teachers, content providers, technology providers), iii) boards and shareholders (education ministry), iv) professional associations (teachers' association) and v) special interest groups (students' commissions).

\subsection{Key Barriers to E-Learning Success}

Previous studies have attempted to identify the determinants of e-learning success [17]. Given the diversified stakeholder's viewpoints, several factors have contributed to the success of the e-learning model [18-20]. Therefore, the barriers to e-learning require an approach that remedies issues to enhance the spread of e-learning under the resources constraint. Seven important components that limit e-learning have been identified (see Figure 1).

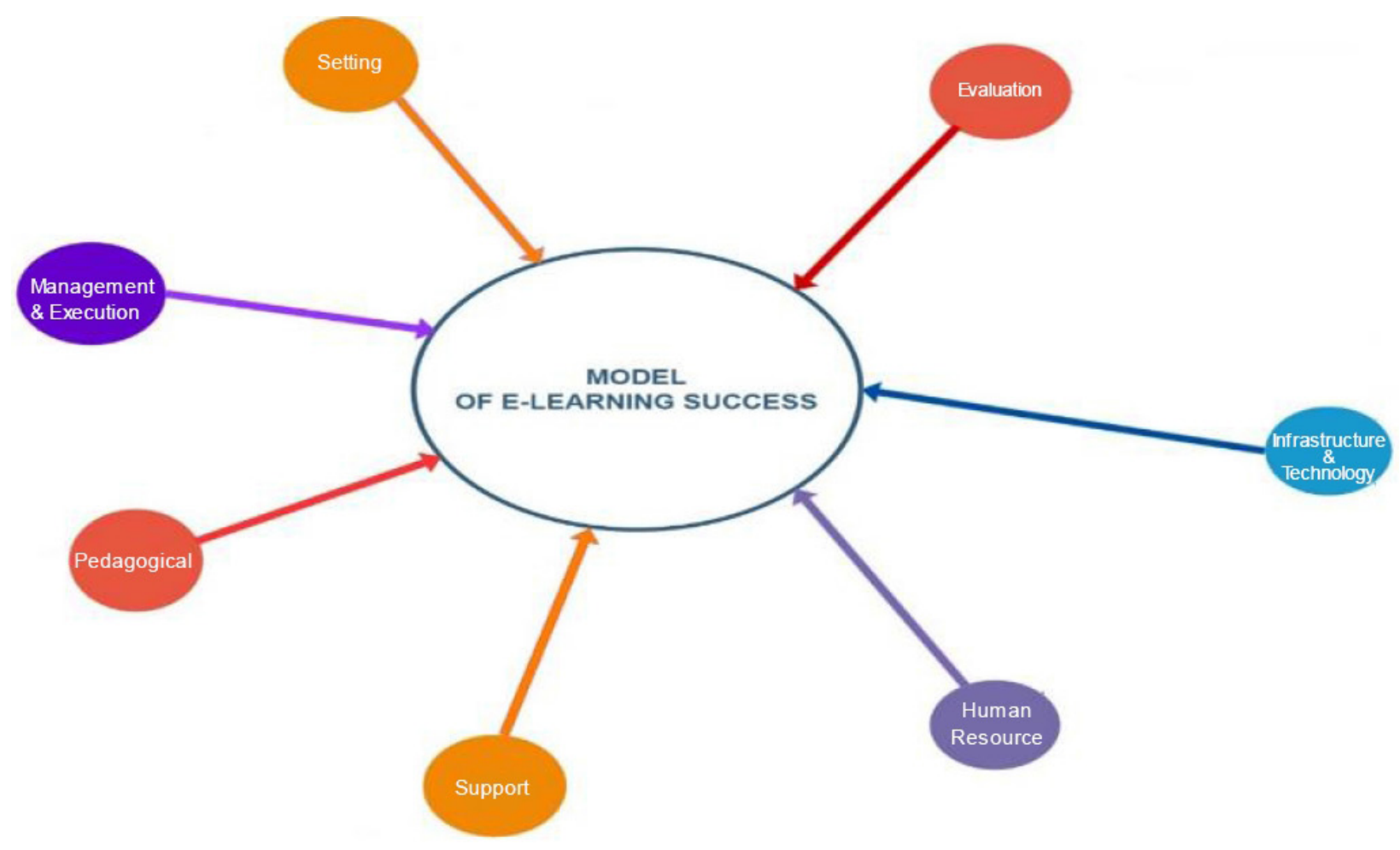

Figure 1. E-learning Success Model 
Infrastructure and technology are the first obstacles to e-learning. From the learners' perspective, the ability to work with computers and online privacy are major restraints. [21]. Esterhuyse and Scholtz [22] further mentioned internet speed, actual site design, and insufficiency of hardware and software (platforms) compatible with modern technology. Another critical factor is settings with diversified dimensions of social, political, cultural, geographical and legal issues [23]. Becker, et al. [21] made a survey in Australia and found that the nature of e-learning significantly hindered e-learning success. Peer isolation, learning effectiveness, the validity of online training, and assessment were the main limitations. As a result, certificates issued by certain authorities have been unaccepted. Therefore, positive attitudes and cooperation towards e-learning are critical for its development [24-26]. This also raises the issue of quality recognition, then the evaluation of e-learning programs, content, and students.

Moreover, human resources are the key driver of any success and e-learning is not an exception [27]. According to Soong, et al. [28], both learners' and teachers' competencies are essential to motivate online learning especially the technical skills of instructors, administrators, and technicians. In addition, support also contributes to e-learning development. Prompt feedback, on-demand assistance, and diversified learning resources have been evidenced to be influential in removing e-learning barriers. Khan [23], in particular, emphasized the role of management and execution. In fact, leadership and institutional culture to ether with the strong support commitment from senior management has benefited the development of e-learning. The management of content, delivery, and maintenance is an added value to its success. Pedagogical approaches, methods, and the process of teaching, and curriculum are important for any kind of education, either face-to-face or e-learning [29].

\section{Research Methodology}

Fuzzy set theory is a special set of mathematical tools that are particularly suited for handling incomplete information or the ambiguity of object classes in the most flexible way [30-38]. The steps of the Chang's extended analysis method under fuzzy environment are as follows [39-41]:

Let $X=\left\{x_{1}, x_{2}, \ldots, x_{n}\right\}$ be an object set, and $U=\left\{u_{1}\right.$, $\left.u_{2}, \ldots, u_{m}\right\}$ be a goal (objective) set.

Then, the $m$ extent analysis values for each $i^{\text {th }}$ object for $m$ goals are obtained and shown as follows $[42,43]$ :

$$
\tilde{M}_{g_{i}}^{j} \text { where } i=1,2, \ldots, n ; j=1,2, \ldots, m
$$

Step 1: Obtain priority weights

The value of fuzzy Chang's extended analysis synthetic on the $i^{\text {th }}$ is expressed as:

$$
S_{i}=\left(\sum_{i=1}^{m} l_{i}, \sum_{i=1}^{m} m_{i}, \sum_{i=1}^{m} u_{i}\right) \otimes\left(\frac{1}{\sum_{i=1}^{n} u_{i}}, \frac{1}{\sum_{i=1}^{n} m_{i}}, \frac{1}{\sum_{i=1}^{n} l_{i}}\right)
$$

Step 2: Comparing degrees of possibility

The degree of possibility of $M_{2}=\left(l_{2}, m_{2}, u_{2}\right) \geq M_{1}=\left(l_{1}\right.$, $\left.m_{1}, u_{l}\right)$ is expressed as follows [44]:

$$
\begin{aligned}
& V\left(M_{2} \geq M_{1}\right)=\operatorname{hgt}\left(M_{1} \cap M_{2}\right)=\mu_{M_{2}}(d) \\
& = \begin{cases}1 & \text { if } m_{2} \geq m_{1} \\
0 & \text { if } 1_{1} \geq u_{2} \\
\frac{l_{1}-u_{2}}{\left(m_{2}-u_{2}\right)-\left(m_{1}-l_{1}\right)} & \text { otherwise }\end{cases}
\end{aligned}
$$

Step 3: Obtaining the weight vector

The degree possibility for a convex fuzzy number to be greater than $k$ convex fuzzy numbers $M_{i}(i=1,2, \ldots, k)$ can be defined by:

$V\left(M \geq M_{1}, M_{2}, \ldots, M_{k}\right)=V\left[\left(M \geq M_{1}\right)\right.$ and $\left(M \geq M_{2}\right)$ and $\left.\ldots\left(M \geq M_{\mathrm{k}}\right)\right]=\min V\left(M \geq M_{i}\right), i=1,2, \ldots, k$.

Assume that

$$
d^{\prime}\left(A_{i}\right)=\min V\left(S_{i} \geq S_{k}\right)
$$

for $k=1,2, \ldots, n ; k \neq i$.

Then, the weight vector is given by:

$$
W^{\prime}=\left(d^{\prime}\left(A_{1}\right), d^{\prime}\left(A_{2}\right), \ldots, d^{\prime}\left(A_{n}\right)\right)^{T}
$$

where $A_{i}(\mathrm{i}=1,2, \ldots, n)$ are $n$ elements.

Step 4: Calculate the normalized weight vector

$$
W=\left(d\left(A_{1}\right), d\left(A_{2}\right), \ldots, d\left(A_{n}\right)\right)^{T}
$$

Step 5. Ranking of the components

After having components weights, the ranking of all components is determined.

\section{Results and Discussion}

E-learning success model is a crucial topic, especially in the context of the Fourth Industry with artificial intelligence (AI), virtual reality (VR) and big data [2, 45-49]. We have solved the problem of the vagueness in human judgement in the comparison matrice when evaluating the barriers to e-learning success, which has been ignored in the literature. Our research provides insights into the key factors determining its development by integrating the literature review and expert knowledge 
in the field. A multi-stakeholder perspective is an innovative approach for a comprehensive model. Moreover, the fuzzy logic technique is useful in ranking the model's components, as shown in Table 1.

Resources are the drivers for growth in economic models. In the case of e-learning, the same can be found with infrastructure and technology. The greater the effects of the application of technology, the better the attitude of students using these technologies [50-52]. Attitude helps ease off the usability, enhances student's academic performance as well as their chance of career success. Universities must apply technologies in their e-learning model to achieve the highest learning outcomes. In particular, accessibility is reflected by the ease of accessing and browsing the Internet on campus. A high access speed, the ease of using web-based courses, and the reliability of communication among students and between students and teachers further inspire students to use e-learning [2, 53-58]. Moreover, technology is one of the three pillars of e-learning evolution history. Technological advancements have promoted all of the three phases of e-learning development, including premise establishment, formation and development, and the contemporary context.

Table 1. Ranking the e-learning success components

\begin{tabular}{|l|c|c|}
\hline Components & Weight & Rank \\
\hline Infrastructure and technology & 0.1700 & 1 \\
\hline Human resource & 0.1668 & 2 \\
\hline Settings & 0.1665 & 3 \\
\hline Evaluation & 0.1597 & 4 \\
\hline Management and execution & 0.1345 & 5 \\
\hline Support & 0.1103 & 6 \\
\hline Pedagogical aspect & 0.0921 & 7 \\
\hline
\end{tabular}

However, human resources are also significant and, in some cases, their role is superior to physical assets. In an e-learning success model, human resources were second followed by infrastructure and technology. In fact, human competence of online learning is required for all stakeholders, including students, teachers (lecturers or facilitators), instructors, technical supporters as well as administrators to motivate participation in the digital world $[14,59]$. Specifically, e-learning favorable attitude and useful perception from teachers are considered as moderating factors for their e-learning competence development. Thus, in order to enhance e-learning, educational institutions should focus on raising teachers' attitudes and awareness about the usefulness of this training method. Professional training courses and a variety of reference materials, as well as appropriate incentive scheme, can motivate teachers to voluntarily participate in online training $[60,61]$.

Moreover, our research findings suggest that the setting has a strong impact. This is justified for the failure of e-learning given a rich infrastructure and technology as well as human resources. Indeed, social and cultural aspects are most severe, especially in the case of Vietnam, where Confucian philosophy guided the country and favored face-to-face classes and the role of the teacher [62-65].

The consequence is unacceptable of online certification made by certain authorities. Therefore, correct evaluations can mitigate this negative attitude. Quality assurance is considered as a solution [66-68]. In Asia, the issue of ensuring the quality of online training is very diverse. Some countries use the same process and standards for assessing the quality of both face-to-face and online education (such as Hong Kong and Singapore). Several other countries have established separate criteria for evaluating the quality of online training, such as Malaysia and Sri Lanka. The lesson for Vietnam educational institutions with e-learning training is a roadmap to promote e-learning quality.

Another factor is the management and execution, which requires strong leadership as well as tight management of content, delivery, and maintenance $[69,70]$. Without a strong commitment from leadership, the institutional mission may go awry and lead to the failure of e-learning. This also benefits the support, which makes available learning resources and communication in place [71, 72]. The pedagogical aspect is the seventh contributor to the e-learning success model. The behind rationale is the role of the curriculum and teaching process.

\section{Conclusions}

Vietnam's economy has witnessed remarkable growth in recent years in the Southeast Asia [73-82]. This achievement is attributed to the nation's high-quality human resource development strategy [83-89]. Each nation and institution is chasing for the goal of human development and e-learning is an excellent educational delivery system for promoting lifelong learning during the Fourth Industrial Revolution [47, 90]. Further, the multi-stakeholder with the budget constraints. Therefore, the findings from this research can efficiently and effectively prioritize the model components for governments and institutions to balance e-learning development with available resources. To facilitate e-learning with proper strategy, institutional factors should be prioritized because this is one goal for multi-purposes, resulting in effective leadership, rational allocation of resources. Positive attitudes towards e-learning from the stakeholder must be cultivated. In this research, only literature reviews and experts' judgments are conducted. Therefore, prudence must be taken in generalizing the research findings in various contexts.

\section{Acknowledgments}

The authors gratefully acknowledge the National 
Technology And Science Program on Education Science, Vietnam Ministry of Education and Training for funding this research. The authors also acknowledge Ho Chi Minh City Open University, Vietnam, for helping this research.

\section{REFERENCES}

[1] H. Rodrigues, F. Almeida, V. Figueiredo, and S. L. Lopes, "Tracking e-learning through published papers: A systematic review," Computers \& Education, vol. 136, pp. 87-98, 2019.

[2] A. Wahyudi et al., "Government policy in realizing basic education metro," International Journal of Innovative Technology and Exploring Engineering, Article vol. 8, no. 9 Special Issue 3, pp. 113-116, 2019.

[3] H. Rodrigues, F. Almeida, V. Figueiredo, and S. L. Lopes, "Mapping key concepts of e-learning and education: a systematic review through published papers," Computers \& Education, 2019.

[4] I. Malawige, "Creating Value in E-Learning: Beyond Triple-Factor to Improve Teaching-Learning Experience," in 2018 18th International Conference on Advances in ICT for Emerging Regions (ICTer), 2018, pp. 142-149: IEEE.

[5] Q. T. Pham and T. P. Tran, "Impact Factors on Using of E-learning System and Learning Achievement of Students at Several Universities in Vietnam," in International Conference on Computational Science and Its Applications, 2018, pp. 394-409: Springer.

[6] G. N. Nguyen, "Designing and using interactive e-books in Vietnam," International Journal of Learning, Teaching and Educational Research, vol. 11, no. 1, 2015.

[7] S. D. Friedman and J. H. Greenhaus, Work and family--allies or enemies: what happens when business professionals confront life choices. Oxford University Press, USA, 2000.

[8] B. S. Wiese, "Successful pursuit of personal goals and subjective well-being," 2007.

[9] N. V. H. Vina, N. Phong Thanh, E. L. Lydia, and K. Shankar, "Measuring Quality of Management to Predict Success of Portfolio- A Review of Factors Effect Project Portfolio Success," Religacion. Journal of Social Sciences and Humanities, vol. 4, no. 19, 09/30 2019.

[10] P. T. Nguyen, T. A. Nguyen, Q. L. H. T. T. Nguyen, V. D. B. Huynh, and K. D. Vo, "Ranking project success criteria in power engineering companies using fuzzy decision-making method," International Journal of Advanced and Applied Sciences, vol. 5, no. 8, pp. 91-94, 2018.

[11] V. D. B. Huynh, Q. L. H. T. T. Nguyen, P. Van Nguyen, and P. T. Nguyen, "Application Partial Least Square Structural Equation to Develop a Job Search Success Measurement Model," Journal of Mechanics of Continua and Mathematical Sciences, vol. 13, no. 5, 2018.

[12] W. Davis, The Best of Success: A Treasury of Success Ideas. Great Quotations Publishing Company, 1988.

[13] D. Persico, S. Manca, and F. Pozzi, "Adapting the technology acceptance model to evaluate the innovative potential of e-learning systems," Computers in Human Behavior, vol. 30, pp. 614-622, 2014.

[14] E. Ansong, R. Boateng, S. L. Boateng, and A. B. Anderson, "The nature of E-learning adoption by stakeholders of a university in Africa," E-Learning and Digital Media, vol. 14, no. 4, pp. 226-243, 2017.

[15] F. Thaufeega, "Institutional and learner readiness for eLearning in the Maldives," Brunel University London, 2016.

[16] M. Aparicio, F. Bacao, and T. Oliveira, "An e-learning theoretical framework," An e-learning theoretical framework, no. 1, pp. 292-307, 2016.

[17] A. Khasawneh, "Technology acceptance and usage in higher education: a case study of e-learning in Hashemite University in Jordan," International Journal of Management in Education, vol. 4, no. 2, pp. 133-145, 2010.

[18] C. W. Holsapple and A. Lee-Post, "Defining, assessing, and promoting e-learning success: An information systems perspective," Decision sciences journal of innovative education, vol. 4, no. 1, pp. 67-85, 2006.

[19] C.-M. Chiu, M.-H. Hsu, S.-Y. Sun, T.-C. Lin, and P.-C. Sun, "Usability, quality, value and e-learning continuance decisions," Computers \& education, vol. 45, no. 4, pp. 399-416, 2005.

[20] H. M. S. Ahmed, "Hybrid E-Learning acceptance model: Learner perceptions," Decision Sciences Journal of Innovative Education, vol. 8, no. 2, pp. 313-346, 2010.

[21] K. L. Becker, C. J. Newton, and S. Sawang, "A learner perspective on barriers to e-learning," Australian Journal of Adult Learning, vol. 53, no. 2, pp. 211-233, 2013.

[22] M. Esterhuyse and B. Scholtz, "Barriers to e-learning in a developing country: An explorative study," in Proceedings of the 9th IDIA conference, 2015.

[23] B. H. Khan, E-learning quick checklist. IGI Global, 2005.

[24] N. M. Ha and N. H. Lam, "The effects of celebrity endorsement on customer's attitude toward brand and purchase intention," International Journal of Economics and Finance, vol. 9, no. 1, pp. 64-77, 2017.

[25] N. M. Ha and H. L. Tam, "Attitudes and purchase intention towards counterfeiting luxurious fashion products in Vietnam," International Journal of Economics and Finance, vol. 7, no. 11, pp. 207-221, 2015.

[26] H. M. Nguyen and B. T. Khoa, "A Study on the Chain of Cost Values-Online Trust: Applications in Mobile Commerce in Vietnam," Journal of Applied Economic Sciences, vol. 14, no. 1, 2019.

[27] K. Saowapakpongchai, "The development of elearning model for higher education in Thailand," in 2010 International Conference on Educational and Network Technology, 2010.

[28] M. B. Soong, H. C. Chan, B. C. Chua, and K. F. Loh, "Critical success factors for on-line course resources," Computers \& education, vol. 36, no. 2, pp. 101-120, 2001.

[29] A. Assareh and M. H. Bidokht, "Barriers to e-teaching and 
e-learning," Procedia Computer Science, vol. 3, pp. 791-795, 2011.

[30] S. Hudaa et al., "Natural language processing utilization in healthcare," International Journal of Engineering and Advanced Technology, vol. 8, no. 6 Special Issue 2, pp. 1117-1120, 2019.

[31] Y. Purnama et al., "Expert System in Detecting Children's Intelligence using Certainty Factor," Journal of Critical Reviews, vol. 7, no. 1, p. 2020, 2019.

[32] Ramakrishnan, M. S. Shabbir, N. M. Kassim, P. T. Nguyen, and D. Mavaluru, "A comprehensive and systematic review of the network virtualization techniques in the IoT," International Journal of Communication Systems, p. e4331, 2020.

[33] N. T. Phong, V. N. Phuc, and T. T. H. L. N. Quyen, "Application of fuzzy analytic network process and topsis method for material supplier selection," in Key Engineering Materials, 2017, vol. 728, pp. 411-415: Trans Tech Publ.

[34] V. D. B. Huynh, P. Van Nguyen, Q. Nguyen, and P. T. Nguyen, "Application of Fuzzy Analytical Hierarchy Process based on Geometric Mean Method to prioritize social capital network indicators," International Journal of Advanced Computer Science and Applications, vol. 9, no. 12, pp. 182-186, 2018.

[35] P. T. Nguyen, N. B. Vu, L. Van Nguyen, L. P. Le, and K. D. Vo, "The Application of Fuzzy Analytic Hierarchy Process (F-AHP) in Engineering Project Management," in 2018 IEEE 5th International Conference on Engineering Technologies and Applied Sciences (ICETAS), 2018, pp. 1-4: IEEE.

[36] N. Bahrami, S. Liu, V. V. Ponkratov, P. T. Nguyen, A. Maseleno, and S. Berti, "Novel load management for renewable generation sources/battery system through cut energy expenditure and generate revenue," International Journal of Ambient Energy, pp. 1-17, 2019.

[37] L. D. Long, D.-H. Tran, and P. T. Nguyen, "Hybrid multiple objective evolutionary algorithms for optimising multi-mode time, cost and risk trade-off problem," International Journal of Computer Applications in Technology, vol. 60, no. 3, pp. 203-214, 2019.

[38] D.-L. Luong, D.-H. Tran, and P. T. Nguyen, "Optimizing multi-mode time-cost-quality trade-off of construction project using opposition multiple objective difference evolution," International Journal of Construction Management, pp. 1-13, 2018.

[39] P. Van Nguyen, P. T. Nguyen, Q. L. H. Thuy, T. Nguyen, and V. D. B. Huynh, "Calculating Weights of Social Capital Index Using Analytic Hierarchy Process," International Journal of Economics and Financial Issues, vol. 6, no. 3, pp. 1189-1193, 2016.

[40] N. T. Phong and N. L. H. T. T. Quyen, "Application fuzzy multi-attribute decision analysis method to prioritize project success criteria," AIP Conference Proceedings, vol. 1903, no. 1, pp. 111-116, 2017.

[41] P. T. Nguyen, "Determination of construction supplier evaluation criteria using word tags," International Journal of Advanced and Applied Sciences, vol. 5, no. 11, pp. 75-79, 2018.
[42] M. K. Moghadam, A. R. M. Jahromi, and A. S. Nooramin, "A fuzzy AHP decision support system for selecting yard cranes in marine container terminals," WMU Journal of Maritime Affairs, vol. 10, no. 2, pp. 227-240, 2011.

[43] İ. Ertuğrul and N. Karakaşoğlu, "Comparison of fuzzy AHP and fuzzy TOPSIS methods for facility location selection," The International Journal of Advanced Manufacturing Technology, vol. 39, no. 7, pp. 783-795, 2008.

[44] U. Cebeci and D. Ruan, "A multi-attribute comparison of Turkish quality consultants by fuzzy AHP," International Journal of Information Technology \& Decision Making, vol. 6, no. 01, pp. 191-207, 2007.

[45] M. Ciolacu, A. F. Tehrani, L. Binder, and P. M. Svasta, "Education 4.0-Artificial Intelligence Assisted Higher Education: Early recognition System with Machine Learning to support Students' Success," in 2018 IEEE 24th International Symposium for Design and Technology in Electronic Packaging(SIITME), 2018, pp. 23-30: IEEE.

[46] I. E. Rakhimbaeva et al., "Integration of the Educational and Didactic Systems in the Training of Future Teachers," (in English), International Journal of Applied Exercise Physiology, Article vol. 8, no. 2.1, pp. 1131-1136, 2019.

[47] A. Maseleno et al., "General theoretical and philosophical aspects of modern education," (in English), Revista San Gregorio, Article no. 32, pp. 211-216, Aug 2019.

[48] K. Dahdouh, A. Dakkak, L. Oughdir, and F. Messaoudi, "Big data for online learning systems," Education and Information Technologies, vol. 23, no. 6, pp. 2783-2800, 2018.

[49] S. Ali, M. A. Uppal, and S. R. Gulliver, "A conceptual framework highlighting e-learning implementation barriers," Information Technology \& People, vol. 31, no. 1, pp. 156-180, 2018.

[50] R. Hartshorne and H. Ajjan, "Examining student decisions to adopt Web 2.0 technologies: theory and empirical tests," Journal of computing in higher education, vol. 21, no. 3, p. $183,2009$.

[51] E. V. Smirnova, B. Ayshwarya, P. T. Nguyen, W. Hashim, and A. Maseleno, "Using Shell Programs in Educational and Methodological Support for Learning Foreign Language," International Journal of Applied Exercise Physiology, vol. 8, no. 2.1, pp. 1027-1032, 2019.

[52] M. Huda et al., "Learning quality innovation through integration of pedagogical skill and adaptive technology," International Journal of Innovative Technology and Exploring Engineering, Article vol. 8, no. 9 Special Issue 3, pp. 1538-1541, 2019.

[53] B. Ayshwarya et al., "Design analysis of web-based employee information system in office of technical implementation unit of education department," International Journal of Recent Technology and Engineering, Article vol. 8, no. 2 Special Issue 3, pp. 1507-1512, 2019.

[54] E. S. Asih, P. T. Nguyen, E. L. Lydia, K. Shankar, W. Hashim, and A. Maseleno, "Mobile E-commerce website for technology-based buying selling services," International Journal of Engineering and Advanced Technology, vol. 8, no. 6, pp. 884-888, 2019. 
[55] I. Iswanto, E. L. Lydia, K. Shankar, P. T. Nguyen, W. Hashim, and A. Maseleno, "Identifying diseases and diagnosis using machine learning," International Journal of Engineering and Advanced Technology, vol. 8, no. 6 Special Issue 2, pp. 978-981, 2019.

[56] A. Muruganantham, P. T. Nguyen, E. L. Lydia, K. Shankar, W. Hashim, and A. Maseleno, "Big data analytics and intelligence: A perspective for health care," International Journal of Engineering and Advanced Technology, vol. 8, no. 6 Special Issue, pp. 861-864, 2019.

[57] B. P. Sutjiatmo et al., "Empowering internet of things (IoT) through big data," International Journal of Engineering and Advanced Technology, vol. 8, no. 6 Special Issue 2, pp. 938-942, 2019.

[58] S. Z. Thalhah, M. Tohir, P. T. Nguyen, K. Shankar, and R. Rahim, "Mathematical Issues in Data Science and Applications for Health care," International Journal of Recent Technology and Engineering, vol. 8, pp. 4153-4156, 2019.

[59] M. Ghoreishi, M. A. Nadi, G. Manshee, and N. Saeedian, "A Thematic Analysis of the Conceptual Framework of E-Learning in Higher Education," Interdisciplinary Journal of Virtual Learning in Medical Sciences, vol. 8, no. 1, 2017.

[60] Q. L. H. T. T. Nguyen, P. T. Nguyen, and V. D. B. Huynh, "Roles of e-learning in higher education," Journal of Critical Reviews, Article vol. 6, no. 4, pp. 7-13, 2019.

[61] D. H. Vu et al., "Success factors framework for the implementation of e-learning systems in Vietnamese universities," Journal of Critical Reviews, Article vol. 6, no. 4, pp. 1-6, 2019.

[62] V. N. Phuc, T. N. Phong, L. H. T. T. N. Quyen, and D. B. H. Vy, "Extended Fuzzy Analytical Hierarchy Process Approach in Determinants of Employees' Competencies in the Fourth Industrial Revolution " International Journal of Advanced Computer Science and Applications, pp. 150-154, 2019.

[63] J. Zhang, "A cultural look at information and communication technologies in Eastern education," Educational Technology Research and Development, vol. 55, no. 3, pp. 301-314, 2007.

[64] P. Ambika et al., "Self-education as a condition of professional and personal development of a future specialist," Religacion. Journal of Social Sciences and Humanities, vol. 4, no. 16, 06/30 2019.

[65] P. Van Nguyen, P. T. Nguyen, Q. L. H. T. T. Nguyen, and V. D. B. Huynh, "Calculating weights of social capital index using analytic hierarchy process," International Journal of Economics and Financial Issues, vol. 6, no. 3, pp. 1189-1193, 2016.

[66] V. D. B. Huynh, Q. Nguyen, P. Nguyen, and P. T. Nguyen, "Application partial least square structural equation to develop a job search success measurement model," Journal of Mechanics of Continua and Mathematical Sciences, vol. 13, no. 5, pp. 50-59, 2018.

[67] P. T. Nguyen, T. A. Nguyen, Q. Nguyen, and V. Huynh, "Application of SWOT for construction company quality management using building information modelling," Journal of Mechanics of Continua and Mathematical
Sciences, vol. 13, no. 05, pp. 25-33, 2018.

[68] P. T. Nguyen et al., "Construction project quality management using building information modeling 360 field," International Journal of Advanced Computer Science and Applications, Article, vol. 9, no. 10, pp. 228-233, 2018.

[69] Y. Budiasih, C. F. B. Hartanto, T. M. Ha, P. T. Nguyen, and T. P. Usanti, "The mediating impact of perceived organisational politics on the relationship between leadership styles and job satisfaction," International Journal of Innovation, Creativity and Change, Article vol. 10, no. 11, pp. 478-495, 2020.

[70] M. Miharja, R. Sacipto, Q. L. H. Thuy to Nguyen, P. T. Nguyen, and T. P. Usanti, "How interactional justice within organisations impacts counterproductive work behaviours and self-efficacy in the presence of performance appraisal satisfaction," International Journal of Innovation, Creativity and Change, Article vol. 10, no. 11, pp. 459-477, 2020.

[71] L. Alfita, A. L. Kadiyono, P. T. Nguyen, W. Firdaus, and I. S. Wekke, "Educating the external conditions in the educational and cultural environment," International Journal of Higher Education, Article vol. 8, no. 8, pp. 34-38, 2019.

[72] H. Qodim, Herningsih, P. T. Nguyen, Q. L. H. T. T. Nguyen, and A. Toding, "Educating the information integration using contextual knowledge and ontology merging in advanced levels," International Journal of Higher Education, Article vol. 8, no. 8, pp. 24-29, 2019.

[73] V. H. Thanh and N. M. Ha, "The effect of Banking relationship on firm performance in Vietnam," International Journal of Economics and Finance, vol. 5, no. 5, pp. 148-158, 2013.

[74] M. H. Nguyen and B. T. Khoa, "Perceived Mental Benefit in Electronic Commerce: Development and Validation," Sustainability, vol. 11, no. 23, p. 6587, 2019.

[75] H. M. Nguyen, "The relationship between urbanization and economic growth," International Journal of Social Economics, 2018.

[76] N. M. Ha, N. D. Le, and P. Trung-Kien, "The impact of urbanization on income inequality: A study in Vietnam," Journal of Risk and Financial Management, vol. 12, no. 3, p. 146, 2019.

[77] N. M. Ha, "Impact of capital structure and cash holdings on firm value: case of firms listed on the Ho Chi Minh Stock Exchange," International Journal of Economics and Financial Issues, vol. 7, no. 1, pp. 24-30, 2017.

[78] N. M. Ha, "The effect of firm's growth on firm survival in Vietnam," International Business Research, vol. 6, no. 5, p. $142,2013$.

[79] P. T. Nguyen, V. N. Nguyen, L. H. Pham, T. A. Nguyen, Q. L. H. T. T. Nguyen, and V. D. B. Huynh, "Application of supply chain management in construction industry," Advances in Science and Technology Research Journal, vol. 12, 2018.

[80] M. C. Ramadhan, R. L. Sinaulan, Maryano, S. Hartati, and P. T. Nguyen, "Regulation and digital economy," Journal of 
Environmental Treatment Techniques, Article vol. 8, no. 1, pp. 237-240, 2020.

[81] N. T. Phong, V. Likhitruangsilp, and M. Onishi, "Developing a stochastic traffic volume prediction model for public-private partnership projects," in AIP Conference Proceedings, 2017, vol. 1903, no. 1, p. 060010: AIP Publishing LLC.

[82] N. T. Phong and N. L. H. T. T. Quyen, "Application fuzzy multi-attribute decision analysis method to prioritize project success criteria," in AIP Conference Proceedings, 2017, vol. 1903, no. 1, p. 070011: AIP Publishing LLC.

[83] M. H. Nguyen, B. T. Tran, and L. T. Huynh, "Relation Between Employees and Customers Affects to the Positive Word of Mouth Through Customer Satisfaction," The Journal of Distribution Science, vol. 17, no. 6, pp. 65-75, 2019.

[84] M. H. Nguyen and B. T. Khoa, "Customer Electronic Loyalty towards Online Business: The role of Online Trust, Perceived Mental Benefits and Hedonic Value," The Journal of Distribution Science, vol. 17, pp. 81-93, 2019.

[85] H. M. Nguyen, C. Nguyen, T. T. Ngo, and L. V. Nguyen, "The effects of job crafting on work engagement and work performance: A study of vietnamese commercial banks," The Journal of Asian Finance, Economics and Business (JAFEB), vol. 6, no. 2, pp. 189-201, 2019.

[86] H. M. Nguyen and B. T. Khoa, "The Relationship between the Perceived Mental Benefits, Online Trust, and Personal Information Disclosure in Online Shopping," The Journal of Asian Finance, Economics and Business (JAFEB), vol. 6, pp. 261-270, 2019.

[87] N. M. Ha and N. V. Luan, "The Effect of Employers' attraction and Social Media On Job Application Attention of Senior Students at Pharmaceutical Universities in Vietnam," International Journal of Business and Society, vol. 19, no. 2, 2018.

[88] N. M. Ha and N. T. An, "Impact of Work-Family Conflict on Job Performance of Nurses Working for Hopitals in Ho Chi Minh City," Journal of Science Ho Chi Minh City Open University, no. 4, p. 16, 2015.

[89] T. A. Nguyen, P. T. Nguyen, and V. Peansupap, "Explaining model for supervisor's behavior on safety action based on their perceptions," ARPN Journal of Engineering and Applied Sciences, vol. 10, no. 20, pp. 9562-9572, 2015.

[90] A. Suharyanto, Nazarudin, P. T. Nguyen, A. I. P. Abrar, and R. Rusli, "Preparation the road student future learning process takes in vocational education," Opcion, Article vol. 35, no. Special Issue 19, pp. 962-975, 2019. 